OPEN ACCESS

Edited by:

Francesco Sofi,

University of Florence, Italy

Reviewed by:

Monica Dinu

University of Florence, Italy

Carla Ferreri,

National Research Council (CNR), Italy

*Correspondence: Yusheng L

liyusheng@csu.edu.cn

Jieyu Liang

jamesliang8@aliyun.com

Specialty section:

This article was submitted to

Nutritional Epidemiology,

a section of the journal

Frontiers in Nutrition

Received: 07 October 2020 Accepted: 25 November 2020 Published: 17 December 2020

Citation:

Zhang Y, Ding J, Guo H, Liang J and Li Y (2020) Associations of Fish and Omega-3 Fatty Acids Consumption

With the Risk of Venous Thromboembolism. A Meta-Analysis of Prospective Cohort Studies.

Front. Nutr. 7:614784. doi: 10.3389/fnut.2020.614784

\section{Associations of Fish and Omega-3 Fatty Acids Consumption With the Risk of Venous Thromboembolism. A Meta-Analysis of Prospective Cohort Studies}

\author{
Yi Zhang ${ }^{1}$, Jun Ding ${ }^{2}$, Hongbin Guo ${ }^{1}$, Jieyu Liang ${ }^{1 *}$ and Yusheng $L^{1 *}$ \\ ${ }^{1}$ Department of Orthopaedics, Xiangya Hospital, Central South University, Changsha, China, ${ }^{2}$ Changsha Social Work \\ College, Changsha, China
}

Objective: This study aims to investigate the effect of fish and omega-3 fatty acids consumption on the risk of VTE.

Methods: A comprehensive literature search in the databases of PubMed, Web of Science, and Embase (up to September 2020), was conducted to identify the prospective cohort studies concerning the associations of fish and omega- 3 fatty acids consumption with the risk of VTE. The pooled relative risk (RR) of VTE for the highest vs. lowest category of fish and omega-3 fatty acids consumption, as well as their corresponding 95\% confidence interval (Cl) were calculated.

Results: A total of seven articles with eight prospective cohort studies were included. Specifically, six studies were related to fish consumption, and the overall multi-variable adjusted RR showed no significant relationship between fish consumption and the risk of $\operatorname{VTE}(\mathrm{RR}=1.02,95 \% \mathrm{Cl}: 0.93-1.11 ; P=0.709)$. In the four studies related to omega-3 fatty acids consumption, the overall multi-variable adjusted RR suggested that omega-3 fatty acids consumption was associated with a lower risk of VTE $(R R=0.89,95 \%$ Cl: 0.80-0.98; $P=0.024)$. Moreover, two studies were related to recurrent VTE, and the overall multi-variable adjusted $\mathrm{RR}$ demonstrated a significant inverse association between omega-3 fatty acids consumption and the risk of recurrent VTE (RR $=0.45$, 95\% Cl: $0.25-0.81 ; P=0.008)$.

Conclusion: Although current evidence is still insufficient to demonstrate any relationship between fish consumption and the risk of VTE, omega-3 fatty acids consumption seems to be associated with a lower risk of both VTE and recurrent VTE. Further large well-designed prospective cohort studies are warranted to elaborate the issues examined in this study.

Keywords: fish consumption, omega-3 fatty acids consumption, venous thromboembolism, meta-analysis, prospective cohort studies 


\section{INTRODUCTION}

Venous thromboembolism (VTE), encompassing deep vein thrombosis (DVT) and pulmonary embolism (PE), is a common cardiovascular disease (CVD) in adult populations (1-3). As a major cause of cardiovascular mortality, VTE constitutes a significant public health burden due to debilitating longterm complications $(4,5)$. In contrast with the declining rate of arterial CVD over the past decades $(6,7)$, the incidence of VTE remains stable or even slightly increased $(8,9)$. Moreover, VTE is also considered as a chronic and recurrent disease. Although anticoagulant therapy efficiently prevents VTE recurrence, approximately one-third of patients suffer recurrent VTE within 10 years $(10,11)$. Furthermore, the risk of mortality in patients with VTE is higher than that in general population (12). Thus, there is an urgent need to reduce the VTE risk. The identification of lifestyle factors influencing VTE appears to be an important step in both primary and secondary prevention.

Fish serves as an important determinant of healthy diet, and omega-3 fatty acids (eicosapentaenoic acid [EPA], docosapentaenoic acid [DPA], and docosahexaenoic acid [DHA]) are identified as key bioactive compounds (13). Omega3 fatty acids are reported to be associated with downregulation of inflammation (14), platelet function (15), platelet-endothelium interactions $(16,17)$, and tissue factor expression (18), which are key pathways in VTE pathogenesis. To our best knowledge, the effect of fish and omega-3 fatty acids consumption on the risk of VTE has been investigated by a number of prospective cohort studies with conflicting results $(13,19-24)$. In 2016, a systematic review also indicated that the epidemiological evidence is insufficient to demonstrate any relationship between fish consumption and risk of VTE (25). However, the estimate effects were not pooled and omega- 3 fatty acids and recurrent VTE were also ignored. To address these issues above, a meta-analysis of prospective cohort studies was therefore systematically performed. It was hypothesized that fish and omega-3 fatty acids consumption was associated with a lower risk of VTE.

\section{METHODS}

\section{Search Strategy}

This meta-analysis was performed according to the Preferred Reporting Items for Systematic review and Meta-analyses (PRISMA) guidelines (26). The electronic databases of PubMed, Web of Science, and Embase were searched up to September 2020 , using a series of logic combinations of keywords and intext words that are related to venous thromboembolism ("venous thromboembolism," "deep vein thrombosis," "pulmonary embolism"), fish ("fish," "seafood"), and omega-3 fatty acids ("fish oil," "omega-3," "n-3 fatty acids," "n-3 fatty acid") (27). No language restrictions were set in the search strategy. We first screened the titles and abstracts of all publications. Then, the full articles were read to identify eligible studies. To avoid missing literature, a manual search was also conducted from the reference lists of all articles selected for inclusion.

\section{Study Selection}

The title and abstract screening of relevant articles was done separately by two researchers (YZ and JD) to identify eligible studies for inclusion. The potentially eligible articles were selected through full text review in line with the inclusion and exclusion criteria according to PICOS strategy. The included studies were required to meet the following criteria: (1) the participants were general population; (2) the exposure of interest was the consumption of fish or omega-3 fatty acids; (3) the comparison was the highest vs. lowest category of exposure; (4) the outcomes included the risk of VTE; (5) prospective cohort studies. The exclusion criteria were listed as follows: (1) duplicated or irrelevant articles; (2) reviews, letters or case reports; (3) randomized controlled trials; (4) non-human studies.

\section{Data Extraction}

Data extraction was conducted by two independent reviewers (YZ and JD); disagreements were resolved by consensus. The following information was collected: first author, year of publication, location, age, gender, sample size, number of cases, follow-up, outcome, category of exposure, effect estimates, and adjustments. The corresponding effect estimates adjusted for the maximum number of confounding variables with corresponding 95\% CIs for the highest vs. lowest level were extracted. For the studies reported effect estimates by gender separately, they were processed independently (22). Moreover, Varraso' study was consisted of two different cohorts: the NHS (Nurses' Health Study) and HPFS (Health Professionals Follow-up Study) (21). They were considered as two independent studies.

\section{Quality Assessment}

Quality assessment was conducted according to the NewcastleOttawa (NOS) criteria for non-randomized studies (28), which is based on three broad perspectives: the selection process of study cohorts, the comparability among different cohorts, and the identification of either the exposure or outcome of study cohorts. Disagreements with respect to the methodological quality were resolved by discussion and mutual-consultation.

\section{Statistical Analyses}

$\mathrm{RR}$ was considered as the common measure of the associations of fish and omega- 3 fatty acids consumption with the risk of VTE, and HR was directly converted into RR. The $I^{2}$ statistic, which measures the percentage of the total variation across studies due to heterogeneity, was examined $\left(I^{2}>50 \%\right.$ was considered heterogeneity). If significant heterogeneity was observed among studies, the random-effects model was used; otherwise, the fixedeffects model was acceptable. Begg's tests were performed to assess the publication bias (29), and statistical analyses were performed using STATA version 11.0 (StataCorp LP, College Station, Texas). A $p$-value $\leq 0.05$ was accepted as statistically significant. Subgroup analysis for sample size, gender, location and adjustment of cigarette smoking, physical activity and hypertension, were conducted. 


\section{RESULTS}

\section{Study Identification and Selection}

Figure 1 represents the detailed flow diagram of articles included in the present meta-analysis. Our initial literature searches yielded a total of 207 potentially relevant articles (PubMed 35, Embase 112, and Web of Science 60). After eliminating 70 duplicated articles, 137 articles were screened by titles and abstracts. 78 irrelevant studies, 22 reviews, case reports or letters, 11 non-human studies, 17 randomized control trials studies and two studies with duplicated or inappropriate data (outcome was PE death) were removed $(30,31)$. Eventually, a total of seven articles with eight prospective studies were identified for this meta-analysis (13, 19-24).

\section{Study Characteristics}

The main characteristics of the included studies were showed in Table 1. These studies were published between 2006 and 2019, which included eight prospective cohort studies. Four studies were performed in USA (19-21) and the other four ones were conducted in European country [Norway $(13,23)$, Denmark (22), Switzerland (24)]. The follow-up duration ranged from 0.5 to 19 years. Five studies included both male and female participants $(13,19,22-24)$, and three studies included only female or male participants $(20,21)$. The sample size ranged from 595 to 80,263. The fish and omega-3 fatty acids consumption was assessed by food-frequency questionnaire (FFQ) in all studies. The diagnosis of VTE was obtained in registered medical record (imaging or autopsy) and food was considered as the source of omega-3 fatty acids in all included studies. Six and four studies were related to the associations of fish (19-23) and omega-3 fatty acids $(19,21,23)$ consumption with the risk of VTE, respectively. Two studies were related to the relationship between omega-3 fatty acids consumption and the risk of recurrent VTE $(13,24)$.

\section{Association Between Fish Consumption and the Risk of VTE}

The overall multi-variable adjusted RR suggested no significant relationship between fish consumption and the risk of VTE (RR $=1.02$, 95\% CI: 0.93-1.11; $P=0.709$ ) (Figure 2). No substantial level of heterogeneity was found among various studies $(P=$ $\left.0.176, I^{2}=33 \%\right)$. Begg's rank-correlation test showed no evidence of publication bias $(P=0.548)$. The results of subgroup analysis were showed in Table 2 . The sensitivity analysis showed only minimal changes in magnitude of the pooled RR when any study was excluded from the meta-analysis, suggesting that no individual study had excessive influence on these robust aggregate results (data not shown).

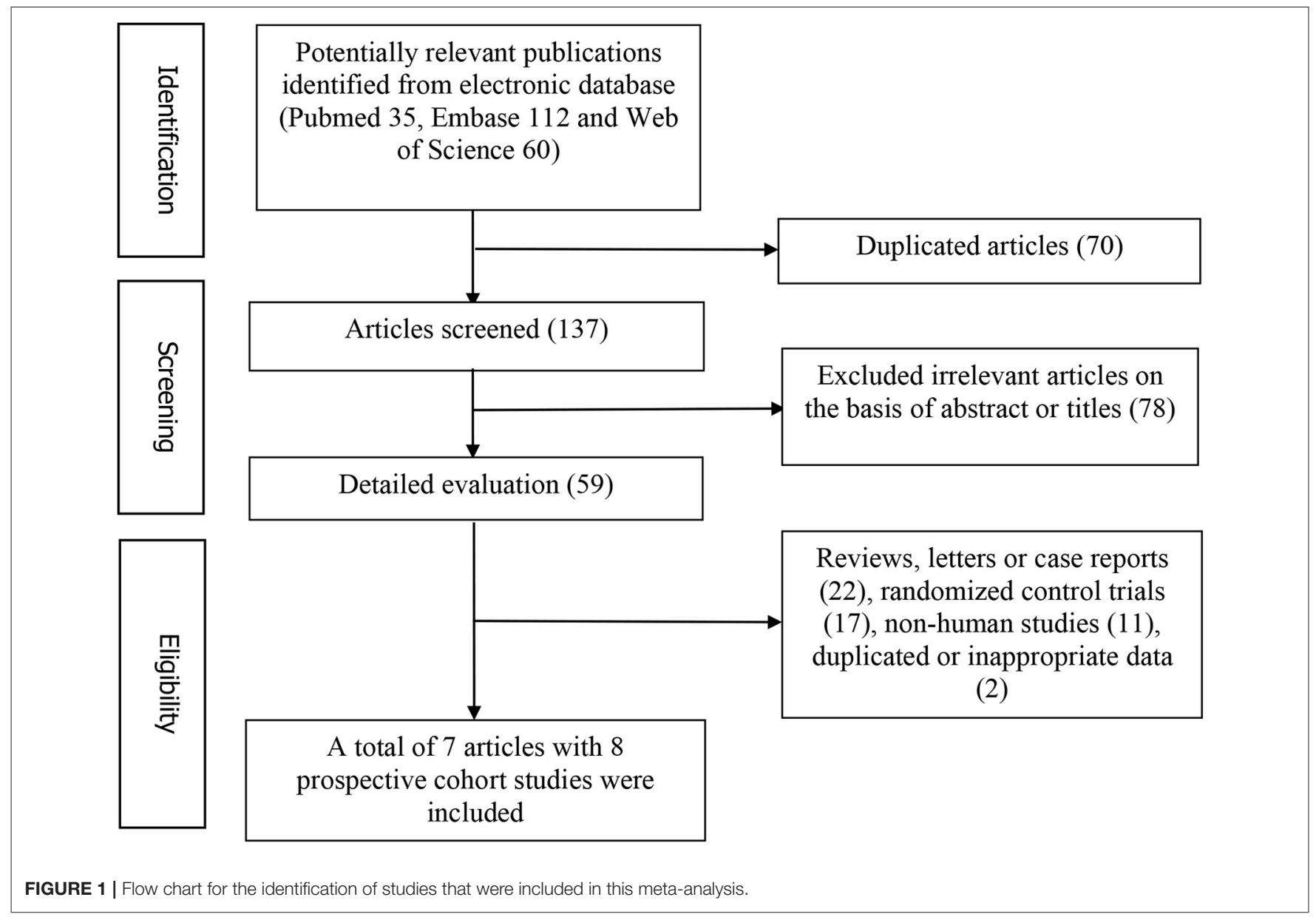


TABLE 1 | Characteristics of the individual studies included in this meta-analysis.

\begin{tabular}{|c|c|c|c|c|c|c|c|c|c|c|c|}
\hline References & Location & $\begin{array}{c}\text { Age and } \\
\text { BMI }\end{array}$ & Gender & $\begin{array}{l}\text { Sample } \\
\text { Size }\end{array}$ & $\begin{array}{l}\text { Number } \\
\text { of cases }\end{array}$ & $\begin{array}{c}\text { Follow-up } \\
\text { years }\end{array}$ & Outcome & $\begin{array}{l}\text { Category of } \\
\text { exposure }\end{array}$ & Effect estimates & Adjustments & NOS \\
\hline Steffen (19) & USA & $\begin{array}{c}54 \\
27.5\end{array}$ & Both & 14,962 & 196 & 12.5 & VTE & $\begin{array}{l}\text { Fish } \\
\text { Quintile 1 } \\
\text { Quintile 2 } \\
\text { Quintile 3 } \\
\text { Quintile } 4 \\
\text { Quintile } 5 \\
\text { Omega-3 Fatty Acids } \\
\text { Quintile 1 } \\
\text { Quintile 2 } \\
\text { Quintile 3 } \\
\text { Quintile } 4 \\
\text { Quintile } 5\end{array}$ & $\begin{array}{c}1 \\
0.58(0.37,0.90) \\
0.60(0.39,0.92) \\
0.55(0.35,0.88) \\
0.70(0.44,1.10) \\
1 \\
0.56(0.36,0.87) \\
0.64(0.42,0.99) \\
0.54(0.34,0.85) \\
0.70(0.43,1.13)\end{array}$ & $\begin{array}{l}\text { Age, race, gender, field center, } \\
\text { energy intake, vitamin } \\
\text { supplement use, BMl, diabetes, } \\
\text { vegetable, fruit, whole grain, red } \\
\text { and processed meat }\end{array}$ & 8 \\
\hline Lutsey (20) & USA & $\begin{array}{c}55-69 \\
27\end{array}$ & Female & 37,393 & 1,950 & 19 & VTE & $\begin{array}{l}\text { Fish } \\
<0.5 \text { Servings/week } \\
0.5-1 \text { Servings/week } \\
1-1.5 \text { Servings/week } \\
1.5-2.5 \text { Servings/week } \\
\geq 2.5 \text { Servings/week }\end{array}$ & $\begin{array}{c}1 \\
1.13(0.95,1.34) \\
1.16(0.98,1.36) \\
1.07(0.91,1.26) \\
1.22(1.03,1.46)\end{array}$ & $\begin{array}{l}\text { Age, energy intake, education, } \\
\text { smoking status, and physical } \\
\text { activity, BMI, diabetes }\end{array}$ & 7 \\
\hline $\begin{array}{l}\text { Varraso } \\
\text { NHS (21) }\end{array}$ & USA & $\begin{array}{c}30-55 \\
25\end{array}$ & Female & 80,263 & 1,540 & 14 & VTE & $\begin{array}{l}\text { Fish } \\
\text { Quintile } 1 \\
\text { Quintile } 2 \\
\text { Quintile } 3 \\
\text { Quintile } 4 \\
\text { Quintile } 5 \\
\text { Omega-3 Fatty Acids } \\
\text { Quintile } 1 \\
\text { Quintile } 2 \\
\text { Quintile } 3 \\
\text { Quintile } 4 \\
\text { Quintile } 5\end{array}$ & $\begin{array}{c}1 \\
0.94(0.80,1.11) \\
0.92(0.79,1.09) \\
0.96(0.82,1.13) \\
0.95(0.80,1.11) \\
1 \\
0.96(0.82,1.12) \\
0.92(0.78,1.08) \\
0.98(0.84,1.15) \\
0.94(0.80,1.10)\end{array}$ & $\begin{array}{l}\text { Age, total physical activity level, } \\
\text { physical inactivity level, BMI, total } \\
\text { caloric intake, smoking, } \\
\text { pack-years of smoking, } \\
\text { race/ethnicity, spouse's } \\
\text { educational attainment, parity, } \\
\text { menopausal status, nonaspirin } \\
\text { nonsteroidal anti-inflammatory } \\
\text { drug use, warfarin use, } \\
\text { multivitamin supplement use, } \\
\text { hypertension, coronary heart } \\
\text { disease, and rheumatologic } \\
\text { disease }\end{array}$ & 9 \\
\hline $\begin{array}{l}\text { Varraso } \\
\text { HPFS (21) }\end{array}$ & USA & $\begin{array}{c}40-75 \\
25\end{array}$ & Male & 49,238 & 1,352 & 12 & VTE & $\begin{array}{l}\text { Fish } \\
\text { Quintile 1 } \\
\text { Quintile 2 } \\
\text { Quintile 3 } \\
\text { Quintile 4 } \\
\text { Quintile 5 } \\
\text { Omega-3 Fatty Acids } \\
\text { Quintile 1 } \\
\text { Quintile 2 } \\
\text { Quintile 3 } \\
\text { Quintile } 4 \\
\text { Quintile } 5\end{array}$ & $\begin{array}{c}1 \\
1.02(0.85,1.22) \\
0.83(0.69,0.99) \\
0.96(0.81,1.15) \\
0.96(0.80,1.14) \\
1 \\
1.01(0.86,1.19) \\
0.88(0.74,1.04) \\
0.91(0.77,1.08) \\
0.91(0.76,1.08)\end{array}$ & $\begin{array}{l}\text { Age, total physical activity level, } \\
\text { physical inactivity level, BMI, total } \\
\text { caloric intake, smoking, } \\
\text { pack-years of smoking, } \\
\text { race/ethnicity, spouse's } \\
\text { educational attainment, parity, } \\
\text { menopausal status, nonaspirin } \\
\text { nonsteroidal anti-inflammatory } \\
\text { drug use, warfarin use, } \\
\text { multivitamin supplement use, } \\
\text { hypertension, coronary heart } \\
\text { disease, and rheumatologic } \\
\text { disease }\end{array}$ & 9 \\
\hline
\end{tabular}


TABLE 1 | Continued

\begin{tabular}{|c|c|c|c|c|c|c|c|c|c|c|c|}
\hline References & Location & $\begin{array}{c}\text { Age and } \\
\text { BMI }\end{array}$ & Gender & $\begin{array}{c}\text { Sample } \\
\text { Size }\end{array}$ & $\begin{array}{l}\text { Number } \\
\text { of cases }\end{array}$ & $\begin{array}{l}\text { Follow-up } \\
\text { years }\end{array}$ & Outcome & $\begin{array}{l}\text { Category of } \\
\text { exposure }\end{array}$ & Effect estimates & Adjustments & NOS \\
\hline $\begin{array}{l}\text { Varraso } \\
\text { HPFS (21) }\end{array}$ & USA & $\begin{array}{c}40-75 \\
25\end{array}$ & Male & 49,238 & 1,352 & 12 & VTE & $\begin{array}{l}\text { Fish } \\
\text { Quintile 1 } \\
\text { Quintile 2 } \\
\text { Quintile 3 } \\
\text { Quintile 4 } \\
\text { Quintile 5 } \\
\text { Omega-3 Fatty Acids } \\
\text { Quintile 1 } \\
\text { Quintile 2 } \\
\text { Quintile 3 } \\
\text { Quintile 14 } \\
\text { Quintile 5 }\end{array}$ & $\begin{array}{c}1 \\
1.02(0.85,1.22) \\
0.83(0.69,0.99) \\
0.96(0.81,1.15) \\
0.96(0.80,1.14) \\
1 \\
1.01(0.86,1.19) \\
0.88(0.74,1.04) \\
0.91(0.77,1.08) \\
0.91(0.76,1.08)\end{array}$ & $\begin{array}{l}\text { Age, total physical activity level, } \\
\text { physical inactivity level, BMI, total } \\
\text { caloric intake, smoking, } \\
\text { pack-years of smoking, } \\
\text { race/ethnicity, spouse's } \\
\text { educational attainment, parity, } \\
\text { menopausal status, nonaspirin } \\
\text { nonsteroidal anti-inflammatory } \\
\text { drug use, warfarin use, } \\
\text { multivitamin supplement use, } \\
\text { hypertension, coronary heart } \\
\text { disease, and rheumatologic } \\
\text { disease }\end{array}$ & 9 \\
\hline $\begin{array}{l}\text { Severinsen } \\
\text { Male (22) }\end{array}$ & Denmark & $\begin{array}{c}50-64 \\
26.2\end{array}$ & Male & 26,674 & 641 & 10.2 & VTE & $\begin{array}{l}\text { Fish } \\
\text { Quintile 1 } \\
\text { Quintile 2 } \\
\text { Quintile } 3 \\
\text { Quintile 4 } \\
\text { Quintile 5 }\end{array}$ & $\begin{array}{c}1 \\
0.98(0.71,1.35) \\
1.09(0.78,1.51) \\
1.02(0.74,1.42) \\
0.90(0.64,1.28)\end{array}$ & $\begin{array}{l}\text { Total energy intake, smoking, } \\
\text { BMl, dietary intake of fruits and } \\
\text { vegetables }\end{array}$ & 7 \\
\hline $\begin{array}{l}\text { Severinsen } \\
\text { Female } \\
\text { (22) }\end{array}$ & Denmark & $\begin{array}{c}50-64 \\
24.8\end{array}$ & Female & 29,340 & 641 & 10.2 & VTE & $\begin{array}{l}\text { Fish } \\
\text { Quintile 1 } \\
\text { Quintile 2 } \\
\text { Quintile 3 } \\
\text { Quintile 4 } \\
\text { Quintile 5 }\end{array}$ & $\begin{array}{c}1 \\
0.70(0.47,1.04) \\
0.74(0.50,1.10) \\
0.85(0.57,1.27) \\
1.19(0.77,1.83)\end{array}$ & $\begin{array}{l}\text { Total energy intake, smoking, } \\
\text { BMI, use of hormone } \\
\text { replacement therapy, dietary } \\
\text { intake of fruits and vegetables }\end{array}$ & 7 \\
\hline Reiner (24) & Switzerland & $\begin{array}{c}75 \\
26.4\end{array}$ & Both & 826 & 97 & 0.5 & $\begin{array}{l}\text { Recurrent } \\
\text { VTE }\end{array}$ & $\begin{array}{l}\text { Omega-3 Fatty Acids } \\
\text { Low } \\
\text { Medium } \\
\text { High }\end{array}$ & $\begin{array}{c}1 \\
0.39(0.15,0.99) \\
0.17(0.03,0.96)\end{array}$ & $\begin{array}{l}\text { Age, gender, BMI, cancer, } \\
\text { provoked VTE, prior VTE and } \\
\text { periods of anticoagulation as a } \\
\text { time-varying covariate }\end{array}$ & 7 \\
\hline $\begin{array}{l}\text { Isaksen } \\
\text { (23) }\end{array}$ & Norway & $\begin{array}{c}25-97 \\
25.5\end{array}$ & Both & 21,970 & 541 & 12.5 & VTE & $\begin{array}{l}\text { Fish } \\
\text { Quartile } 1 \\
\text { Quartile } 2 \\
\text { Quartile } 3 \\
\text { Quartile } 4 \\
\text { Omega-3 Fatty Acids } \\
\text { Quartile } 1 \\
\text { Quartile } 2 \\
\text { Quartile } 3 \\
\text { Quartile } 4\end{array}$ & $\begin{array}{c}1 \\
0.93(0.71,1.23) \\
0.98(0.75,1.27) \\
0.99(0.76,1.29) \\
1 \\
0.74(0.57,0.96) \\
0.77(0.59,0.99) \\
0.78(0.61,1.00)\end{array}$ & Age, sex and BMl & 8 \\
\hline $\begin{array}{l}\text { Isaksen } \\
\text { (13) }\end{array}$ & Norway & $\begin{array}{c}25-97 \\
27.4\end{array}$ & Both & 595 & 98 & 12.5 & $\begin{array}{l}\text { Recurrent } \\
\text { VTE }\end{array}$ & $\begin{array}{l}\text { Omega-3 Fatty Acids } \\
\text { Quartile } 1 \\
\text { Quartile } 2 \\
\text { Quartile } 3\end{array}$ & $\begin{array}{c}1 \\
1.01(0.61,1.66) \\
0.51(0.27,0.95)\end{array}$ & Age, sex, and BMl & 7 \\
\hline
\end{tabular}




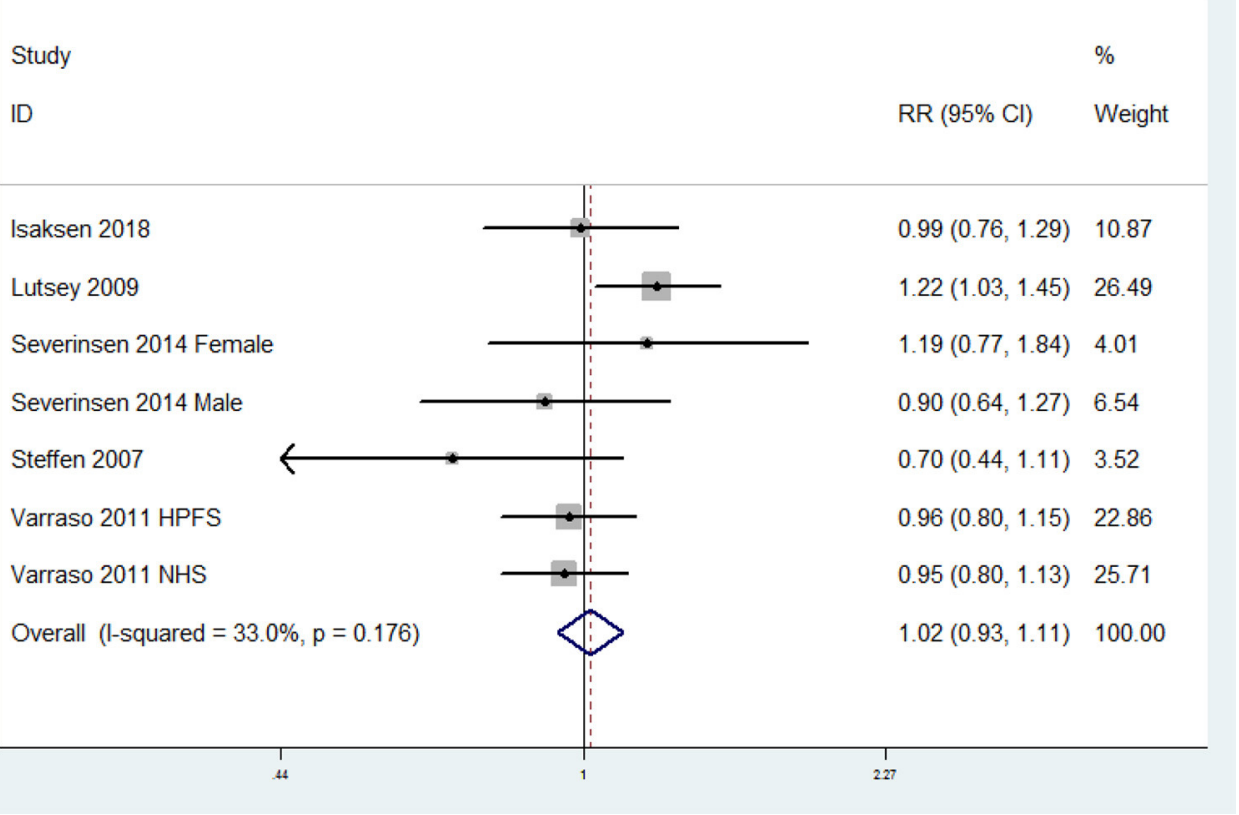

FIGURE 2 | Forest plot of meta-analysis: Overall multi-variable adjusted RR of VTE for the highest vs. lowest category of fish consumption.

\section{Association Between Omega-3 Fatty Acids Consumption and the Risk of VTE}

The overall multi-variable adjusted RR suggested that omega3 fatty acids consumption was associated with a lower risk of VTE (RR $=0.89,95 \%$ CI: $0.80-0.98 ; P=0.024)$ (Figure 3). No substantial level of heterogeneity was found among various studies $\left(P=0.469, I^{2}=0 \%\right)$. Begg's rank-correlation test showed no evidence of publication bias $(P=0.308)$. The results of subgroup analysis were showed in Table 3 . The sensitivity analysis showed only minimal changes in magnitude of the pooled RR when any study was excluded from the meta-analysis, suggesting that no individual study had excessive influence on these robust aggregate results (data not shown).

\section{Association Between Omega-3 Fatty Acids Consumption and the Risk of Recurrent VTE}

The overall multi-variable adjusted RR showed that omega-3 fatty acids consumption was associated with a lower risk of recurrent VTE $(\mathrm{RR}=0.45,95 \%$ CI: $0.25-0.81 ; P=0.008)$ (Figure 4). No substantial level of heterogeneity was found among various studies $\left(P=0.244, I^{2}=26.4 \%\right)$. Begg's rank-correlation test showed no evidence of publication bias $(P=1.00)$.

\section{DISCUSSIONS}

In the present meta-analysis, a total of eight prospective cohort studies were identified for examination. No significant relationship between fish consumption and the
TABLE 2 | Subgroup analyses of fish consumption and the risk of VTE.

\begin{tabular}{|c|c|c|c|c|}
\hline Subgroup & $\begin{array}{l}\text { Number of } \\
\text { studies }\end{array}$ & $\begin{array}{c}\text { Pooled } \\
\text { RR }\end{array}$ & $95 \% \mathrm{Cl}$ & Heterogeneity \\
\hline All & 6 & 1.02 & $0.93-1.11$ & $P=0.18 ; l^{2}=33 \%$ \\
\hline \multicolumn{5}{|l|}{ Sample size } \\
\hline$<30,000$ & 2 & 0.91 & $0.72-1.14$ & $P=0.20 ; I^{2}=38 \%$ \\
\hline$>30,000$ & 4 & 1.04 & $0.94-1.14$ & $P=0.18 ; l^{2}=36 \%$ \\
\hline \multicolumn{5}{|l|}{ Gender } \\
\hline Male & 2 & 0.95 & $0.81-1.11$ & $P=0.74 ; I^{2}=0 \%$ \\
\hline Female & 3 & 1.09 & $0.90-1.32$ & $P=0.12 ; I^{2}=54 \%$ \\
\hline \multicolumn{5}{|l|}{ Location } \\
\hline USA & 4 & 1.00 & $0.84-1.18$ & $P=0.05 ; l^{2}=62 \%$ \\
\hline Other & 2 & 1.00 & $0.82-1.20$ & $P=0.61 ; I^{2}=0 \%$ \\
\hline \multicolumn{5}{|c|}{ Adjustment of cigarette smoking } \\
\hline Adjusted & 4 & 1.04 & $0.94-1.14$ & $P=0.18 ; I^{2}=36 \%$ \\
\hline Unadjusted & 2 & 0.91 & $0.72-1.14$ & $P=0.20 ; I^{2}=38 \%$ \\
\hline \multicolumn{5}{|c|}{ Adjustment of physical activity } \\
\hline Adjusted & 3 & 1.04 & $0.88-1.22$ & $P=0.07 ; I^{2}=62 \%$ \\
\hline Unadjusted & 3 & 0.95 & $0.80-1.13$ & $P=0.41 ; I^{2}=0 \%$ \\
\hline \multicolumn{5}{|c|}{ Adjustment of hypertension } \\
\hline Adjusted & 2 & 0.95 & $0.84-1.08$ & $P=0.93 ; I^{2}=0 \%$ \\
\hline Unadjusted & 4 & 1.08 & $0.96-1.22$ & $P=0.13 ; l^{2}=43 \%$ \\
\hline
\end{tabular}

risk of VTE was obtained, whereas omega-3 fatty acids consumption was associated with a lower risk of both VTE and recurrent VTE. 


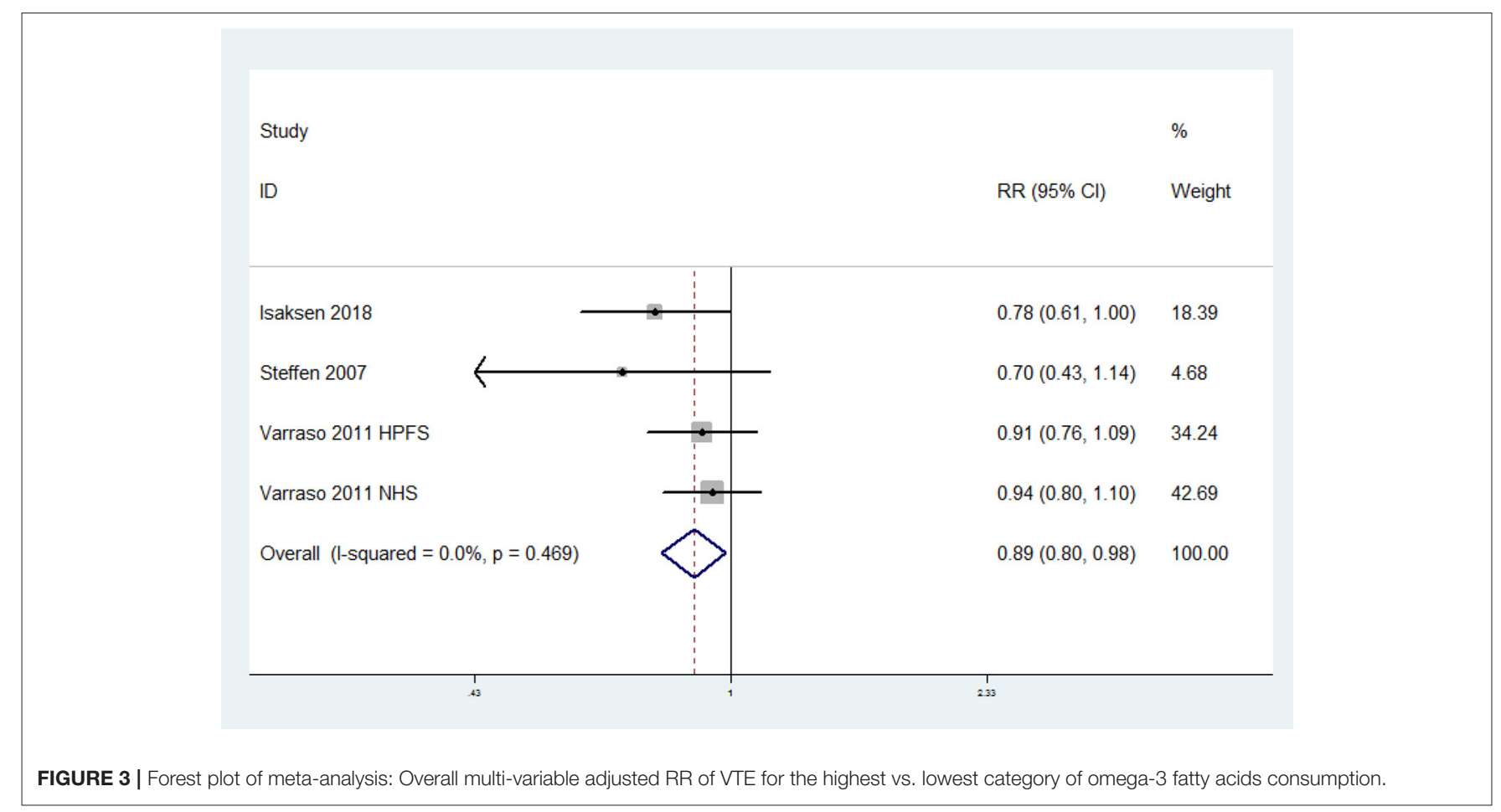

TABLE 3 | Subgroup analyses of omega-3 fatty acids consumption and the risk of VTE.

\begin{tabular}{|c|c|c|c|c|}
\hline Subgroup & $\begin{array}{l}\text { Number of } \\
\text { studies }\end{array}$ & $\begin{array}{l}\text { Pooled } \\
\text { RR }\end{array}$ & $95 \% \mathrm{Cl}$ & Heterogeneity \\
\hline All & 4 & 0.89 & $0.80-0.98$ & $P=0.47 ; I^{2}=0 \%$ \\
\hline \multicolumn{5}{|c|}{ Sample size } \\
\hline$<30,000$ & 2 & 0.76 & $0.61-0.95$ & $P=0.70 ; I^{2}=0 \%$ \\
\hline$>30,000$ & 2 & 0.93 & $0.82-1.04$ & $P=0.79 ; I^{2}=0 \%$ \\
\hline \multicolumn{5}{|l|}{ Gender } \\
\hline Male & 1 & 0.91 & $0.76-1.09$ & / \\
\hline Female & 1 & 0.94 & $0.80-1.10$ & / \\
\hline \multicolumn{5}{|l|}{ Location } \\
\hline USA & 3 & 0.91 & $0.81-1.02$ & $P=0.53 ; I^{2}=0 \%$ \\
\hline Other & 1 & 0.78 & $0.61-1.00$ & 1 \\
\hline \multicolumn{5}{|c|}{$\begin{array}{l}\text { Adjustment of cigarette } \\
\text { smoking }\end{array}$} \\
\hline Adjusted & 2 & 0.93 & $0.82-1.04$ & $P=0.79 ; I^{2}=0 \%$ \\
\hline Unadjusted & 2 & 0.76 & $0.61-0.95$ & $P=0.70 ; I^{2}=0 \%$ \\
\hline \multicolumn{5}{|c|}{$\begin{array}{l}\text { Adjustment of physical } \\
\text { activity }\end{array}$} \\
\hline Adjusted & 2 & 0.93 & $0.82-1.04$ & $P=0.79 ; I^{2}=0 \%$ \\
\hline Unadjusted & 2 & 0.76 & $0.61-0.95$ & $P=0.70 ; I^{2}=0 \%$ \\
\hline \multicolumn{5}{|c|}{ Adjustment of hypertension } \\
\hline Adjusted & 2 & 0.93 & $0.82-1.04$ & $P=0.79 ; I^{2}=0 \%$ \\
\hline Unadjusted & 2 & 0.76 & $0.61-0.95$ & $P=0.70 ; I^{2}=0 \%$ \\
\hline
\end{tabular}

Several studies have demonstrated the impact from omega-3 fatty acids on downregulation of inflammation (14), tissue factor expression $(18,32)$, platelet function (15), platelet-endothelium interactions $(16,17)$, and hepatic excretion of coagulation factors (33), which are significant molecular pathways in VTE pathogenesis. Omega-3 fatty acids may also alternate cell membrane permeability and functionality, which leads to antiarrhythmic properties (14). Moreover, some randomized control trials demonstrated that omega-3 fatty acids (both supplementation and circulating level) was associated with a lower risk of VTE after orthopedics surgery $(34,35)$. On the other hand, a cross-sectional observational study also found a negative relationship between fish consumption and VTE (36). These findings strongly support the potential beneficial effect of omega3 fatty acids. However, inconsistent results were obtained with regard to experimental animal study. One study demonstrated that omega-3 fatty acids could prevent VTE (37), while some other studies rejected it $(38,39)$. These inconsistent results in rodents may be difficult to translate to human, especially elderly patients with various risk factors. Moreover, the differences in VTE pathophysiology may account for this discrepancy. The low-dose and long-term protective mechanisms of omega-3 fatty acids may apply to elderly patients with chronic proinflammatory and pro-thrombotic backgrounds, whereas animal models consist of an acute and short-term injury with a relatively short exposure to omega-3 fatty acids (24). Therefore, further animal study will be helpful to deepen our understanding.

Notably, this topic has been discussed by a systematic review in 2016 by Mattiuzzi et al. (25). It claimed that the epidemiological evidence was insufficient to demonstrate any relationship between fish consumption and the risk of VTE. However, the estimate effects were not pooled and omega-3 fatty acids and recurrent VTE were also ignored. It also indicated that cigarette smoking and physical activity should be considered as 


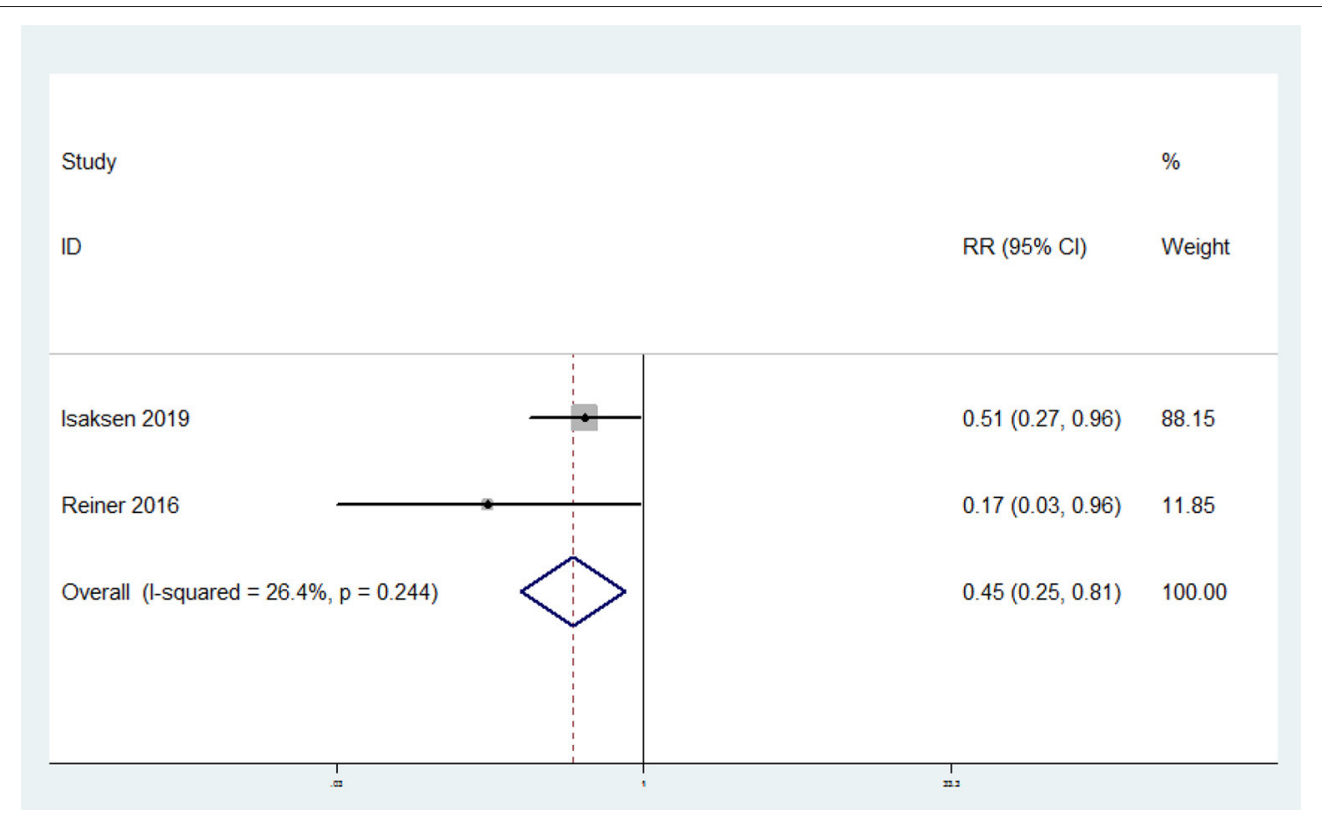

FIGURE 4 | Forest plot of meta-analysis: Overall multi-variable adjusted RR of recurrent VTE for the highest vs. lowest category of omega-3 fatty acids consumption.

confounders. To address these issues above, the present study was therefore systematically preformed. We found an inverse association between omega-3 fatty acids consumption and the risk of VTE, which disappeared when cigarette smoking, physical activity and hypertension was adjusted (Table 3 ). Nevertheless, the reliability of results may be reduced by the small number of studies. As a consequence, more studies with adjustment of these confounding factors are still needed.

So far, the bioavailability of the omega-3 fatty acids is rarely considered in defeating diseases. The formation of phospholipids and regulation of membrane properties are closely associated with the biological effect of omega-3 fatty acids. For example, the omega-3 fatty acids content in erythrocyte membranes (40) and fatty acid-based membrane lipidomics (41) are served as important reliable indicator for omega-3 fatty acids consumption. On the contrary, as the most general indicator, FFQ could not reflect its biological effective quantity in the body. Further studies with bioavailability of omega-3 fatty acids are still needed. On the other hand, as another important polyunsaturated fatty acid, omega- 6 fatty acids should also be considered. The metabolites of omega- 6 fatty acids are proinflammatory/proaggregatory agent (42), which contributes to the risk of all-cause mortality, coronary heart disease mortality and cardiovascular events (43). Indeed, omega-3 and omega-6 fatty acids are supposed to balance each other when they are consumed in the diet at a ratio of around 1 to 1 (44). The increase in omega-6/omega-3 fatty acids ratio could shift the balance into a proinflammatory/proaggregatory state, and contributed to platelet aggregation, coagulation and thrombosis (44). Therefore, more studies with detail information on omega- 6 fatty acids consumption are needed.
Interestingly, the associations of fish and omega- 3 fatty acids consumption with the risk of VTE are inconsistence. Several speculations may account for this discrepancy. First, the reliability of the results might be weakened since only limited studies were included. Second, some neglected substances might work against the effect of omega- 3 fatty acids since the components in fish are rather complicated. Third, the processing method of fish may also matter. The effect from fresh fish consumption on VTE risk was stronger than that from dried or salted fish, steamed fish paste and deepfried fish (omega-3 fatty acids were mainly derived from fresh fish) (31). Fourth, the content of omega-3 fatty acids in fatty fish can be up to 7-8 folds higher than that in lean fish. It is possible that a high intake of (lean) fish is associated with a relatively low intake of omega-3 fatty acids (23). On the other hand, different results were obtained with regard to the category of VTE (provoked and unprovoked, DVT and PE) $(13,23)$. However, the limitation of current evidence precluded a subgroup analysis. More well-designed prospective cohort studies with fish and VTE specification are needed.

Our study has several strengths. First, this is the first metaanalysis of prospective cohort studies aiming at the associations of fish and omega-3 fatty acids consumption with the risk of VTE based on the most comprehensive literature search to date. Second, most of the included studies were analyzed based on adjusted results and large samples. Third, our result may be helpful for health professionals and policy makers to better consider the effect of diet on VTE risk. However, this meta-analysis was also limited in some aspects. First, due to the limitation of relevant literature, only 8 prospective cohort 
studies were identified. Second, the classification of exposure may vary greatly among individuals. Third, the selection of adjusted factors was not uniform. Fourth, only a few studies have considered the processing method of fish and category of fish (lean and fatty) or VTE (provoked and unprovoked, DVT and PE), some issues could not be addressed. Last but not the least, the consumption of omega- 6 fatty acids, which could influence the results of our study, was not considered. These limitations might weaken the significance of this study.

\section{CONCLUSIONS}

Although current evidence is still insufficient to demonstrate any relationship between fish consumption and the risk of VTE, omega-3 fatty acids consumption seems to be associated with a lower risk of both VTE and recurrent VTE. However, further well-designed prospective cohort studies are still needed.

\section{DATA AVAILABILITY STATEMENT}

The original contributions presented in the study are included in the article/Supplementary Material, further inquiries can be directed to the corresponding author/s.

\section{REFERENCES}

1. Huang W, Goldberg R, Anderson F, Kiefe C, Spencer F. Secular trends in occurrence of acute venous thromboembolism: the Worcester VTE study (1985-2009). Am J Med. (2014) 127:82939. doi: 10.1016/j.amjmed.2014.03.041

2. Naess I, Christiansen S, Romundstad P, Cannegieter S, Rosendaal F, Hammerstrøm J. Incidence and mortality of venous thrombosis: a population-based study. J Thromb Haemost. (2007) 5:6929. doi: 10.1111/j.1538-7836.2007.02450.x

3. Cushman M, Tsai A, White R, Heckbert S, Rosamond W, Enright P, et al. Deep vein thrombosis and pulmonary embolism in two cohorts: the longitudinal investigation of thromboembolism etiology. Am J Med. (2004) 1:19-25. doi: 10.1016/j.amjmed.2004.01.018

4. Heit J. Venous thromboembolism: disease burden, outcomes and risk factors. J Thromb Haemost. (2005) 3:1611-7. doi: 10.1111/j.1538-7836.2005.01415.x

5. Silverstein M, Heit J, Mohr D, Petterson T, O'Fallon W, Melton L. Trends in the incidence of deep vein thrombosis and pulmonary embolism: a 25-year population-based study. Arch Intern Med. (1998) 158:58593. doi: 10.1001/archinte.158.6.585

6. Mannsverk J, Wilsgaard T, Mathiesen E, Løchen M, Rasmussen $\mathrm{K}$, Thelle $\mathrm{D}$, et al. Trends in modifiable risk factors are associated with declining incidence of hospitalized and nonhospitalized acute coronary heart disease in a population. Circulation. (2016) 133:74-81. doi: 10.1161/CIRCULATIONAHA.115.016960

7. Vangen-Lønne A, Wilsgaard T, Johnsen S, Løchen M, Njølstad I, Mathiesen E. Declining incidence of ischemic stroke: what is the impact of changing risk factors? the Tromsø study 1995 to 2012. Stroke. (2017) 48:54450. doi: 10.1161/STROKEAHA.116.014377

8. Arshad $\mathrm{N}$, Isaksen $\mathrm{T}$, Hansen J, Brækkan $\mathrm{S}$. Time trends in incidence rates of venous thromboembolism in a large cohort recruited from the general population. Eur $J$ Epidemiol. (2017) 32:299-305. doi: 10.1007/s10654-017-0238-y

\section{AUTHOR CONTRIBUTIONS}

YZ conceived the idea, performed the statistical analysis, and drafted this meta-analysis. YZ and JD selected retrieved relevant papers. HG assessed each study. JL and YL were the guarantors of the overall content. All authors revised and approved the final manuscript.

\section{FUNDING}

This work was supported by National Key R\&D Program of China (2019YFA0111900), National Natural Science Foundation of China (No. 81874030, 82072506), Provincial Natural Science Foundation of Hunan (2020JJ3060, 2019JJ40517), InnovationDriven Project of Central South university (No. 2020CX045), Wu Jieping Medical Foundation (320.6750.2020-03-14), CMA Young and Middle-aged Doctors Outstanding Development ProgramOsteoporosis Specialized Scientific Research Fund Project (G-X2019-1107-12), and the Key program of Health Commission of Hunan Province (20201902).

\section{SUPPLEMENTARY MATERIAL}

The Supplementary Material for this article can be found online at: https://www.frontiersin.org/articles/10.3389/fnut.2020. 614784/full\#supplementary-material

9. Heit J, Ashrani A, Crusan D, McBane R, Petterson T, Bailey K. Reasons for the persistent incidence of venous thromboembolism. Thromb Haemost. (2017) 117:390-400. doi: 10.1160/TH16-07-0509

10. Mozaffarian D, Benjamin E, Go A, Arnett D, Blaha M, Cushman $\mathrm{M}$, et al. Heart disease and stroke statistics-2015 update: a report from the American Heart Association. Circulation. (2015) 131:29-322. doi: 10.1161/CIR.0000000000000152

11. Konstantinides S, Torbicki A, Agnelli G, Danchin N, Fitzmaurice D, Galiè N, et al. 2014 ESC Guidelines on the diagnosis and management of acute pulmonary embolism. Kardiol Pol. (2014) 72:997-1053. doi: 10.5603/KP.2014.0211

12. Søgaard K, Schmidt M, Pedersen L, Horváth-Puhó E, Sørensen H. 30-year mortality after venous thromboembolism: a population-based cohort study. Circulation. (2014) 130:82936. doi: 10.1161/CIRCULATIONAHA.114.009107

13. Isaksen $\mathrm{T}$, Evensen $\mathrm{L}$, Brækkan $\mathrm{S}$, Hansen J. Dietary intake of marine polyunsaturated n-3 fatty acids and risk of recurrent venous thromboembolism. Thromb Haemost. (2019) 119:205363. doi: 10.1055/s-0039-1697663

14. Surette M. The science behind dietary omega-3 fatty acids. CMAJ. (2008) 178:177-80. doi: 10.1503/cmaj.071356

15. Hansen J, Olsen J, Wilsgård L, Lyngmo V, Svensson B. Comparative effects of prolonged intake of highly purified fish oils as ethyl ester or triglyceride on lipids, haemostasis and platelet function in normolipaemic men. Eur J Clin Nutr. (1993) 47:497-507.

16. Hansen J, Svensson B, Wilsgård L, Osterud B. Serum enriched with n-3 polyunsaturated fatty acids inhibits procoagulant activity in endothelial cells. Blood Coagul Fibrinolysis. (1991) 2:515-9. doi: 10.1097/00001721-199108000-00004

17. Caterina R, Cybulsky M, Clinton S, Gimbrone M, Libby P. Omega-3 fatty acids and endothelial leukocyte adhesion molecules. Prostaglandins Leukot Essent Fatty Acids. (1995) 52:191-5. doi: 10.1016/0952-3278(95) 90021-7 
18. Moertl D, Berger R, Hammer A, Hutuleac R, Koppensteiner R, Kopp C. Dose-dependent decrease of platelet activation and tissue factor by omega3 polyunsaturated fatty acids in patients with advanced chronic heart failure. Thromb Haemost. (2011) 106:457-65. doi: 10.1160/TH11-03-0169

19. Steffen L, Folsom A, Cushman M, Jacobs D, Rosamond W. Greater fish, fruit, and vegetable intakes are related to lower incidence of venous thromboembolism: the Longitudinal Investigation of Thromboembolism Etiology. Circulation. (2007) 115:188-95. doi: 10.1161/CIRCULATIONAHA.106.641688

20. Lutsey P, Steffen L, Virnig B, Folsom A. Diet and incident venous thromboembolism: the Iowa Women's Health Study. Am Heart J. (2009) 157:1081-7. doi: 10.1016/j.ahj.2009.04.003

21. Varraso R, Kabrhel C, Goldhaber S, Rimm E, Camargo C. Prospective study of diet and venous thromboembolism in US women and men. Am J Epidemiol. (2012) 175:114-26. doi: 10.1093/aje/kwr377

22. Severinsen M, Overvad K, Andersen V, Tjønneland A, Schmidt E, Kristensen S. Fish intake and venous thromboembolism: a Danish follow-up study. Thromb Res. (2014) 133:352-6. doi: 10.1016/j.thromres.2013.12.018

23. Isaksen T, Evensen L, Johnsen S, Jacobsen B, Hindberg K, Brækkan S, et al. Dietary intake of marine n-3 polyunsaturated fatty acids and future risk of venous thromboembolism. Res Pract Thromb Haemost. (2018) 3:5969. doi: $10.1002 / \mathrm{rth} 2.12168$

24. Reiner M, Stivala S, Limacher A, Bonetti N, Méan M, Egloff M, et al. Omega3 fatty acids predict recurrent venous thromboembolism or total mortality in elderly patients with acute venous thromboembolism. J Thromb Haemost. (2017) 15:47-56. doi: 10.1111/jth.13553

25. Mattiuzzi C, Cervellin G, Franchini M, Lippi G. Fish intake and venous thromboembolism: a systematic literature review. Clin Appl Thromb Hemost. (2016) 22:309-13. doi: 10.1177/1076029615585992

26. Liberati A, Altman D, Tetzlaff J, Mulrow C, Gøtzsche P, Ioannidis J, et al. The PRISMA statement for reporting systematic reviews and meta-analyses of studies that evaluate healthcare interventions: explanation and elaboration. BMJ. (2009) 339:b2700. doi: 10.1136/bmj.b2700

27. Morvaridzadeh M, Sepidarkish M, Yavari M, Tahvilian N, Heydarian A, Khazdouz $M$, et al. The effects of omega-3 fatty acid supplementation on inflammatory factors in HIV-infected patients: a systematic review and meta-analysis of randomized clinical trials. Cytokine. (2020) 136:155298. doi: 10.1016/j.cyto.2020.155298

28. Zhang Y, Zhang D. Relationship between nut consumption and metabolic syndrome: a meta-analysis of observational studies. J Am Coll Nutr. (2019) 38:499-505. doi: 10.1080/07315724.2018.1561341

29. Begg B, Mazumdar M. Operating characteristics of a rank correlation test for publication bias. Biometrics. (1994) 50:1088-101. doi: 10.2307/2533446

30. Hansen-Krone I, Enga K, Südduth-Klinger J, Mathiesen E, Njølstad I, Wilsgaard T, et al. High fish plus fish oil intake is associated with slightly reduced risk of venous thromboembolism: the Tromsø Study. J Nutr. (2014) 144:861-7. doi: 10.3945/jn.113.189548

31. Ohira T, Iso H, Yamagishi K, Tamakoshi A, JACC Study Group. Fish intake and death from pulmonary embolisms among Japanese men and womenThe Japan Collaborative Cohort (JACC) study. Circ J. (2018) 82:206370. doi: 10.1253/circj.CJ-18-0040

32. Hansen J, Olsen J, Wilsgård L, Osterud B. Effects of dietary supplementation with cod liver oil on monocyte thromboplastin synthesis, coagulation and fibrinolysis. J Intern Med Suppl. (1989) 731:133-9. doi: 10.1111/j.1365-2796.1989.tb01447.x

33. Vanschoonbeek K, Wouters K, Meijden P, Gorp P, Feijge M, Herfs M, et al. Anticoagulant effect of dietary fish oil in hyperlipidemia: a study of hepatic gene expression in APOE2 knock-in mice. Arterioscler Thromb Vasc Biol. (2008) 28:2023-9. doi: 10.1161/ATVBAHA.107.156992
34. Zheng X, Jia R, Li Y, Liu T, Wang Z. Omega-3 fatty acids reduce postoperative risk of deep vein thrombosis and pulmonary embolism after surgery for elderly patients with proximal femoral fractures: a randomized placebo-controlled, double-blind clinical trial. Int Orthop. (2020) 44:208993. doi: 10.1007/s00264-020-04610-0

35. Shiozawa J, Miyazaki T, Nagayama M, Kaneko H, Hiki M, Hada S, et al. Serum polyunsaturated fatty acid (PUFAS) levels as a risk factor for the postoperative development of venous thromboembolism (VTE) in patients with end-stage knee osteoarthritis who receiving Total Knee Arthroplasty (TKA). Osteoarth Cartil. (2016) 24:S514. doi: 10.1016/j.joca.2016. 01.941

36. Bhoopat L, Rojnuckarin $\mathrm{P}$, Hiransuthikul $\mathrm{N}$, Intragumtornchai T. Low vegetable intake is strongly associated with venous thromboembolism in Thai population. Blood Coagul Fibrinolysis. (2010) 21:758-63. doi: 10.1097/MBC.0b013e3283403537

37. Kuma H, Nagashima R, Hatae H, Tsuda T, Hamasaki N. Beneficial effect of EPA (20:5 n-3 PUFA) on preventing venous thromboembolism: a rat tail thrombosis model experiment. Thromb Res. (2013) 131:1078. doi: 10.1016/j.thromres.2012.09.014

38. Reiner M, Martinod K, Stivala S, Savarese G, Camici G, Lüscher T, et al. Dietary omega-3 alpha-linolenic acid does not prevent venous thrombosis in mice. Thromb Haemost. (2015) 113:177-84. doi: 10.1160/TH1403-0200

39. Andriamampandry M, Leray C, Freund M, Cazenave J, Gachet C. Antithrombotic effects of (n-3) polyunsaturated fatty acids in rat models of arterial and venous thrombosis. Thromb Res. (1999) 93:9-16. doi: 10.1016/S0049-3848(98)00149-2

40. Stark K, Van Elswyk M, Higgins M, Weatherford C, Salem N. Global survey of the omega-3 fatty acids, docosahexaenoic acid and eicosapentaenoic acid in the blood stream of healthy adults. Prog Lipid Res. (2016) 63:13252. doi: 10.1016/j.plipres.2016.05.001

41. Ferreri C, Masi A, Sansone A, Giacometti G, Larocca A, Menounou G, et al. Fatty acids in membranes as homeostatic, metabolic and nutritional biomarkers: recent advancements in analytics and diagnostics. Diagnostics. (2016) 7:1. doi: 10.3390/diagnostics7010001

42. DiNicolantonio J, O'Keefe J. Importance of maintaining a low omega6/omega-3 ratio for reducing inflammation. Open Heart. (2018) 5:e000946. doi: 10.1136/openhrt-2018-000946

43. Ramsden C, Zamora D, Leelarthaepin B, Majchrzak-Hong S, Faurot K, Suchindran $\mathrm{C}$, et al. Use of dietary linoleic acid for secondary prevention of coronary heart disease and death: evaluation of recovered data from the Sydney Diet Heart Study and updated meta-analysis. BMJ. (2013) 346:e8707. doi: 10.1136/bmj.e8707

44. DiNicolantonio J, O'Keefe J. Importance of maintaining a low omega-6/omega-3 ratio for reducing platelet aggregation, coagulation and thrombosis. Open Heart. (2019) 6:e001011. doi: 10.1136/openhrt-2019-001011

Conflict of Interest: The authors declare that the research was conducted in the absence of any commercial or financial relationships that could be construed as a potential conflict of interest.

Copyright (c) 2020 Zhang, Ding, Guo, Liang and Li. This is an open-access article distributed under the terms of the Creative Commons Attribution License (CC BY). The use, distribution or reproduction in other forums is permitted, provided the original author(s) and the copyright owner(s) are credited and that the original publication in this journal is cited, in accordance with accepted academic practice. No use, distribution or reproduction is permitted which does not comply with these terms. 